\title{
The effect of dietary L-carnitine on the growth performance in fingerlings of the African catfish (Clarias gariepinus) in relation to dietary lipid
}

\author{
BY ELS TORREELE, AD VAN DER SLUISZEN AND JOHAN VERRETH* \\ Department of Fish Culture and Fisheries, Wageningen Agricultural University, PO Box 338, \\ 6700 AH Wageningen, The Netherlands
}

(Received 29 July 1991-Accepted 12 November 1991)

\begin{abstract}
The effect of dietary L-carnitine on the growth and growth efficiency of African catfish (Clarias gariepinus, Burchell 1822) fingerlings was investigated. Six dietary levels of $\mathrm{L}$-carnitine, varying from the control level (about $125 \mathrm{mg} / \mathrm{kg}$ ) to $3920 \mathrm{mg} / \mathrm{kg}$, were each tested at two dietary lipid levels ( 96 and $155 \mathrm{~g} / \mathrm{kg}$ ). The diets were isonitrogenous and were fed to thirty-six experimental groups of 100 fish weighing $5 \mathrm{~g}$ at a feeding level of $25.2 \mathrm{~g} / \mathrm{kg}$ live weight $(w)^{08}$ per d, during $18 \mathrm{~d}$. The average final weight varied from 19.1 to $28.0 \mathrm{~g}$. At a dietary lipid level of $96 \mathrm{~g} / \mathrm{kg}$ the metabolic growth increased from 30.8 to $36.5 \mathrm{~g} / \mathrm{kg} \mathrm{w}^{0.8}$ per d. At the higher dietary lipid level the metabolic growth increased from 30.9 to $35.4 \mathrm{~g} / \mathrm{kg} \mathrm{w}^{0.8}$ per $\mathrm{d}$. To assess the dose-response relationship between dietary L-carnitine and growth performance in the African catfish a linear-plateau model was fitted to the experimental data. According to this model, metabolic growth was at a maximum at L-carnitine levels of $500 \mathrm{mg} / \mathrm{kg}$ and above at a lipid level of $96 \mathrm{~g} / \mathrm{kg}$ and at $\mathrm{L}$-carnitine levels of $684 \mathrm{mg} / \mathrm{kg}$ and above at a lipid level of $155 \mathrm{~g} / \mathrm{kg}$. The fitted maximum metabolic growth was higher at a dietary lipid level of $96 \mathrm{~g} / \mathrm{kg} \mathrm{(35.9} \mathrm{g} / \mathrm{kg} \mathrm{w}^{0.8}$ per d) than at $155 \mathrm{~g} / \mathrm{kg} \mathrm{(34.7} \mathrm{g} / \mathrm{kg} \mathrm{w}^{0.8}$ per d). Feed conversion improved significantly with increasing dietary levels of $\mathrm{L}$-carnitine, reaching a fitted plateau at $\mathrm{L}$-carnitine levels of 448.8 and $236.7 \mathrm{mg} / \mathrm{kg}$ respectively for the high and low dietary fat levels. Other growth efficiency variables, e.g. protein efficiency ratio, protein retention and energy retention improved accordingly. Taking into consideration that all fish received the same amount of feed, the results of the present study demonstrate that the positive effect of increased levels of dietary L-carnitine is the result of an improved feed utilization, probably because of a stimulated protein-sparing action.
\end{abstract}

L-Carnitine: Fat intake: Fish nutrition: African catfish

In most vertebrate animals the oxidation of long-chain fatty acids is dependant on the presence of L-carnitine, which allows long-chain acyl-CoA-esters to cross the mitochondrial membrane. Inside these mitochondria $\beta$-oxidation takes place (Bremer, 1983; Borum, 1987; Stryer, 1988). As such, L-carnitine plays a vital role in fat combustion. It has been suggested that L-carnitine supplementation may stimulate protein-sparing action by increasing energy derived from lipids.

Several studies on chickens, pigs, dogs, rats, sea bass (Dicentrarchus labrax), channel catfish (Ictalurus punctatus) and trout (Onchorynchus mykiss) demonstrate a growth improvement by feeding extra dietary L-carnitine (Bilinski \& Jonas, 1970; Bremer, 1983; Santulli \& D'Amelio, 1986a, b; Borum, 1987; Feller \& Rudman, 1988; Santulli et al. 1988; Burtle, 1993; K. D. Günther, unpublished results). L-carnitine addition to diets of channel 
catfish and sea bass resulted in a reduction of body and liver lipid content (Santulli et al. 1988; Burtle, 1993). Presumably the growth improvement and lipid reduction are a result of a more efficient use of dietary lipid.

Fish diets are characterized by a relatively high protein content $(450-550 \mathrm{~g} / \mathrm{kg}$ dry matter). Fish have an impaired capacity for carbohydrate utilization. Protein and fat are the most important energy sources for fish. Since protein is the most expensive feed component for fish culture, feeding an energy-rich (fat-rich) diet has several advantages. An increased dietary fat content could induce a protein-sparing action and improve the utilization of dietary protein. Further, an improved protein efficiency might reduce $\mathrm{N}$ emission in fish-farm effluents.

For the African catfish (Clarias gariepinus), the addition of substantial amounts of dietary lipid has a limited practical value. It results in excess fat deposition and growth reduction (Machiels \& Henken, 1986). Therefore, supplementation of diets of African catfish with L-carnitine may alleviate some of these constraints, allowing the use of higherfat diets.

The objective of the present study was to investigate the effect of dietary L-carnitine on growth performance and body composition of the African catfish. It was suggested that the effect of dietary L-carnitine on growth performance would be affected by dietary lipid level; thus, two dietary lipid levels were tested.

\section{MATERIAL AND METHODS \\ Fish and facilities}

Fingerlings of the African catfish (Clarias gariepinus) were obtained from a commercial fingerling farmer. On arrival the average wet weight ranged from 3 to $3 \cdot 5 \mathrm{~g}$. All fish were from the same reproduction batch and had an identical nutritional history.

The experiment was done in the experimental facilities of the Department of Fish Culture and Fisheries of the Wageningen Agricultural University. Fish were kept in thirty-six aquaria of 40 litres volume each, connected to a recirculation system.

\section{Experimental feed and feeding}

Experimental feeds were provided by Trouw BV, Putten and consisted of a commercial trout pellet (Trouvit 1). To test whether increased dietary L-carnitine concentrations may induce an increased lipotropic effect, the experiment was carried out according to a twofactorial design, with six dietary L-carnitine levels $(125,245,490,1960$ and $3920 \mathrm{mg} / \mathrm{kg}$ ) and two fat levels (70 and $140 \mathrm{~g} / \mathrm{kg}$ ). Most feed ingredients of animal origin (e.g. fish meal) contain variable amounts of L-carnitine, leading to low concentrations of L-carnitine in commercial diets. The control diets contained the lower level of dietary L-carnitine $(125 \mathrm{mg} / \mathrm{kg})$; all other diets were supplemented with pure L-carnitine (Lonza Ltd, Basel, Switzerland) to attain the desired levels. The highest level $(3920 \mathrm{mg} / \mathrm{kg})$ was assumed to be equivalent to the optimal dietary L-carnitine level for channel catfish (Burtle, 1993), taking into account the differences in dietary fat level between the present study and that of Burtle (1991) with channel catfish. In the latter, Burtle (1993) detected an optimal dietary Lcarnitine of $1000 \mathrm{mg} / \mathrm{kg}$ when feeding a diet containing $30 \mathrm{~g}$ fat $/ \mathrm{kg}$ to $12 \mathrm{~g}$ juvenile channel catfish.

After preparation, the L-carnitine and fat levels of the feeds differed slightly from intended levels (Table 1). The final L-carnitine levels corresponded well with the preset values (Table 1). The final fat levels $(96$ and $155 \mathrm{~g} / \mathrm{kg}$ represented the range of normal to high fat levels for African catfish. Fat was replaced with carbohydrates. All diets were isonitrogenous, with a protein content of approximately $560 \mathrm{~g} / \mathrm{kg}$ dry matter. 
Table 1. Estimated and actual concentration of dietary L-carnitine in the feeds

\begin{tabular}{|c|c|c|c|c|c|c|c|}
\hline \multirow{2}{*}{$\begin{array}{c}F \\
\text { (g/kg DM) }\end{array}$} & \multicolumn{2}{|c|}{$\begin{array}{l}\text { L-carnitine } \\
(\mathrm{mg} / \mathrm{kg})\end{array}$} & \multirow{2}{*}{$\begin{array}{c}\mathrm{DM} \\
(\mathrm{g} / \mathrm{kg})\end{array}$} & \multirow{2}{*}{$\begin{array}{c}\mathbf{P} \\
(\mathrm{g} / \mathrm{kg} \mathrm{DM})\end{array}$} & \multirow{2}{*}{$\begin{array}{c}\mathrm{CHO}^{*} \\
(\mathrm{~g} / \mathrm{kg} \mathrm{DM})\end{array}$} & \multirow{2}{*}{$\underset{(\mathrm{KJ} / \mathrm{g})}{\mathrm{En}}$} & \multirow{2}{*}{$\begin{array}{c}\text { Ash } \\
(\mathrm{g} / \mathrm{kg} \mathrm{DM})\end{array}$} \\
\hline & Estimated & Actual & & & & & \\
\hline \multirow[t]{6}{*}{96} & 125 & 121 & 910 & 561 & 265 & $18 \cdot 5$ & 103 \\
\hline & 245 & 230 & 918 & 569 & 259 & $18 \cdot 9$ & 103 \\
\hline & 450 & 480 & 918 & 569 & 259 & $19 \cdot 3$ & 102 \\
\hline & 980 & 581 & 920 & 569 & 259 & $19 \cdot 0$ & 102 \\
\hline & 1960 & 1934 & 920 & 560 & 259 & $19 \cdot 4$ & 100 \\
\hline & 3920 & 3951 & 927 & 564 & 262 & $18 \cdot 8$ & 103 \\
\hline \multirow[t]{6}{*}{155} & 125 & 127 & 931 & 566 & 189 & $20 \cdot 3$ & 105 \\
\hline & 245 & 256 & 943 & 573 & 180 & $20 \cdot 7$ & 107 \\
\hline & 490 & 496 & 923 & 572 & 183 & $20 \cdot 2$ & 105 \\
\hline & 980 & 934 & 929 & 565 & 190 & $20 \cdot 4$ & 104 \\
\hline & 1960 & nd & 928 & 572 & 183 & $20 \cdot 5$ & 105 \\
\hline & 3920 & nd & 933 & 569 & 187 & $20 \cdot 7$ & 105 \\
\hline
\end{tabular}

F, fat; DM, dry matter; P, protein; CHO, carbohydrate; En, energy content of the feed (KJ/g); nd, not determined.

* $1000-($ Protein + fat + ash (all g/kg DM)).

During the experiment the fish were fed four times daily, between 11.00 and 23.00 hours, at a feeding level of $25.2 \mathrm{~g} / \mathrm{kg}$ live weight $(\mathrm{w})^{0.8}$ per $\mathrm{d}$. This feeding level results in about $80 \%$ of the maximum growth performance of the African catfish ( $L$. T. N. Heinsbroek, personal communication). Fish were pair-fed during the experiment and, because of the relatively short duration of the experiment $(18 \mathrm{~d})$, rations were not adjusted for eventual growth differences; thus, each fish received the same total amount of feed during the experiment.

\section{Experimental procedure}

In pilot trials the fish consistently developed a Flexibacter columnaris infection due to transport and manipulation stress. For the definitive experiment a preventive treatment with Furaltodone was given $(50 \mathrm{mg} / 1$ for $24 \mathrm{~h}$; Post, 1987). The treatment was repeated after $2 \mathrm{~d}$. Before the experiment began there was an adaptation period of 2 weeks. During this period the fish were raised to $5-5.5 \mathrm{~g}$ by feeding them on a commercial trout pellet (Trouvit 0 ) twice daily until satiation.

To decrease the risk of disease due to stress and fighting, the fish were kept continuously in the dark. The temperature and osmolarity of the water were measured daily. Once weekly, nitrite, nitrate, ammonia, $\mathrm{pH}$ and $\mathrm{O}_{2}$ concentrations were measured. The levels remained below critical values. The outlets of the aquaria were cleaned daily to maintain a maximum water flow through the system. Each day, dead fishes were removed, counted and the daily feed amount was adjusted to the remaining number of fish by assuming a $1: 1$ food conversion ratio, based on previous experiments.

The initial stocking density at the start of the experiment was 100 fish with an average initial weight ranging from $5 \cdot 1$ to $6 \cdot 3 \mathrm{~g}$ (Table 2). The experiment was carried out with three replications ( $n$ 36).

\section{Analytical procedures}

Both at the start and at the end of the experiment the fish were counted and the individual wet weight in each aquarium was estimated by dividing the total biomass per aquarium by the number of fish. At both sampling points (day 0 and day 17) a random sample of fifty 
fish was taken for body composition analysis and stored at $-18^{\circ}$ until analysed. After freeze-drying, dry matter $\left(4 \mathrm{~h}\right.$ at $\left.105^{\circ}\right)$, energy (combustion in a bomb calorimeter, IKA-C-700), protein (nitrogen $\times 6.25$ ) and ash contents (at $500^{\circ}$ ) were measured. All analyses were run in duplicate.

For each aquarium, packed cell volume was determined to check the condition of the tested fish. Blood was sampled from five randomly selected fish per aquarium, collected in tubes containing sodium citrate and subsequently centrifuged $(3000 \mathrm{~g}, 10 \mathrm{~min})$.

\section{Statistical analysis}

Daily growth rates were expressed on a per $\mathrm{kg}$ metabolic weight $\left(\mathrm{w}^{0 \cdot 8}\right)$ basis, using thereby the geometric mean weight $\left(\left(\ln W_{\mathrm{t}}-\ln W_{0}\right) / t\right)$. Growth efficiency was assessed from values for feed conversion (FC; $g$ intake/g weight gain), protein efficiency ratio (PER; $g$ weight gain $/ g$ protein intake), protein retention (PR; protein growth/protein intake $\times 100 \%$ ) and energy retention (ER; energy growth/energy intake $\times 100 \%$ ).

The variables were tested for normality and homogeneity of variances using the UNIVARIATE procedure (SAS, 1985) and Levene's test for homogeneity (Sokal \& Rohlf, 1981) respectively.

Treatment effects on growth and growth efficiency were tested by a two-way analysis of variance according to the model:

$$
Y_{i j k}=\mu+[C]_{i}+[F]_{j}+\left[C^{*} F\right]_{i j}+e_{i j k},
$$

where $Y_{i j k}$ is dependent variable, $\mu$ is experimental mean, $[C]_{i}$ is effect of dietary $\mathrm{L}$-carnitine level $(\mathrm{i}=1,2 \ldots 6),[F]_{j}$ is effect of dietary fat level $(\mathrm{j}=1,2),\left[C^{*} F\right]_{i j}$ is interaction term, $e_{i j k}$ is the remainder.

In case of significant treatment effects $(P<0.05)$, differences between treatment means were tested by Duncan's multiple-range test (Sokal \& Rohlf, 1981).

For both dietary fat levels, dose-response curves were fitted to the values for metabolic growth (MG) and FC. It was assumed that increasing levels of dietary L-carnitine would result in a proportional effect on $\mathrm{MG}$ and $\mathrm{FC}$ with $\mathrm{L}$-carnitine as the most limiting factor. A linear-plateau model composed of two linear lines was fitted to the data; a firstly linear increasing line, reflecting the proportional effect of $\mathrm{L}$-carnitine when it is limiting (equation 2), changing into a horizontal line when L-carnitine is no longer limiting and $\mathrm{MG}$ or $\mathrm{FC}$ is maximum or minimum level respectively (equation 3 ).

The first part of the dose-response curve was fitted by:

$$
Y=a+b^{*} X,
$$

where $Y$ is variable value, $X$ is $\log _{2}$ of the dietary L-carnitine level, $b$ is slope i.e. $(c-a) / X_{m}$, where $a$ is intercept, $c$ is plateau level of growth rate, $X_{m}$ is $\log _{2}$ L-carnitine level at which $c$ is reached.

The second (horizontal) part of the curve was fitted by:

$$
Y=c \text {, }
$$

where $Y$ is variable value, $c$ is plateau value at $X_{m}$. Variables were estimated using an iterative procedure, starting with values within the range of experimental results. The variable estimation was based on the Fortran programme zXMLIN (ISML, 1984). The programme output yielded an estimation for the intercept $a(0 \mathrm{mg}$ L-carnitine $/ \mathrm{kg})$, the plateau level $c$ and the $X_{m}$ value $b$ (dietary L-carnitine level) at which this plateau level is reached. 


\section{RESULTS}

The experimental results are summarized in Table 2.

\section{Packed cell volume and mortality}

The average mortality during the experiment was less than $1 \%$. No clinical infection was noticed during the experiment. The packed cell volume levels ranged from 42.5 (SE 4.7) to $46 \cdot 3$ (SE $6 \cdot 1) \%$ and were not significantly affected by the treatments $(P=0.0341)$. The colour of the plasma ranged from yellow to pale yellow.

\section{Growth}

Values for weight gain are shown in Fig. 1. The final average weight ranged from $19 \cdot 1$ to $28.0 \mathrm{~g}$, i.e. a 3.2-4.5-fold weight increase during the experimental period of $18 \mathrm{~d}$. These values were used to calculate MG, FC, PER, PR and ER.

At the $96 \mathrm{~g}$ dietary lipid $/ \mathrm{kg}$ level, MG ranged from $30.8 \mathrm{~g} / \mathrm{kg} \mathrm{w}^{0.8}$ per $\mathrm{d}$ at the control level of L-carnitine $(121 \mathrm{mg} / \mathrm{kg})$ to $36.5 \mathrm{~g} / \mathrm{kg} \mathrm{w}^{0.8}$ per $\mathrm{d}$ at a dietary L-carnitine level of $1934 \mathrm{mg} / \mathrm{kg}$. For the diets containing $155 \mathrm{~g} \mathrm{lipid} / \mathrm{kg}, \mathrm{MG}$ increased from $30.9 \mathrm{~g} / \mathrm{kg} \mathrm{w}^{\mathbf{0}}$ per $\mathrm{d}$ at the control level $(127 \mathrm{mg} / \mathrm{kg})$ to $35.4 \mathrm{~g} / \mathrm{kg} \mathrm{w}^{0.8}$ per $\mathrm{d}$ at a dietary $\mathrm{L}$-carnitine level of $934 \mathrm{mg} / \mathrm{kg}$. This corresponds with a maximal growth increase of 18.5 and $14.6 \%$ respectively, due to L-carnitine supplementation. All tested dietary L-carnitine levels higher than the control levels (about $125 \mathrm{mg} / \mathrm{kg}$ ) resulted in a significantly higher $\mathrm{MG}$ $(P=0.0256)$. MG did not differ significantly between the two tested dietary fat levels $(P=0 \cdot 1615)$. The interaction term in the two-way ANOVA had no effect on the MG either $(P=0 \cdot 8685)$.

The linear-plateau model described well the dose-response relationship between dietary L-carnitine and MG (coefficient of determination $\left(R^{2}\right) 0.98$ ). According to the fitted linear-plateau model, MG increased linearly with increasing dietary L-carnitine levels up to 500.4 and $683.8 \mathrm{mg} / \mathrm{kg}$ for the diets with 96 and $155 \mathrm{~g}$ fat $/ \mathrm{kg}$ respectively (Fig. 2). Above these levels MG reached a plateau at $35.9 \mathrm{~g} / \mathrm{kg} \mathrm{w}^{0.8}$ per $\mathrm{d}$ for the $96 \mathrm{~g}$ fat $/ \mathrm{kg}$ diet and at $34.7 \mathrm{~g} / \mathrm{kg} \mathrm{w}^{0.8}$ per $\mathrm{d}$ for the $155 \mathrm{~g}$ fat $/ \mathrm{kg}$ diet.

\section{Body composition}

Body protein content was not affected by dietary treatment. The dietary fat level had a significant effect on body fat content, resulting in fatter fish at the $155 \mathrm{~g}$ fat $/ \mathrm{kg}$ level $(P=0.0285)$.

\section{Growth efficiency}

FC for the control diets (L-carnitine levels of 121 and $127 \mathrm{mg} / \mathrm{kg}$ ) was 0.78 and 0.75 respectively for the diets containing 96 and $155 \mathrm{~g}$ fat $/ \mathrm{kg}$. For both dietary fat levels FC decreased with increasing L-carnitine levels, reaching a minimum of 0.62 at $1934 \mathrm{mg} \mathrm{L}$ carnitine $/ \mathrm{kg}$ for the $96 \mathrm{~g}$ fat $/ \mathrm{kg}$ diet and 0.65 at $3920 \mathrm{mg} \mathrm{L}$-carnitine $/ \mathrm{kg}$ for the $155 \mathrm{~g} \mathrm{fat} / \mathrm{kg}$ diet (Table 2). The analysis of variance showed a significant effect of L-carnitine level $(P=0.0317)$. The difference between FC due to dietary fat and the interaction L-carnitine $x$ fat were not significant ( $P=0.3365$ and $P=0.6618$ respectively).

The linear-plateau model fitted the plateau levels at 0.64 for the $96 \mathrm{~g}$ fat $/ \mathrm{kg}$ diet and at 0.68 for the $155 \mathrm{~g}$ fat $/ \mathrm{kg}$ diet; the plateau levels were reached at dietary L-carnitine levels of 448.8 and $236.7 \mathrm{mg} / \mathrm{kg}$ respectively (Fig. 3 ).

PER reached a maximum of 3.10 at $1934 \mathrm{mg} \mathrm{L}$-carnitine $/ \mathrm{kg}$ and 2.95 at $3920 \mathrm{mg} \mathrm{L}$ carnitine $/ \mathrm{kg}$ for the 96 and $155 \mathrm{~g}$ fat $/ \mathrm{kg}$ levels. Analysis of variance did not reveal a 
E. TORREELE AND OTHERS

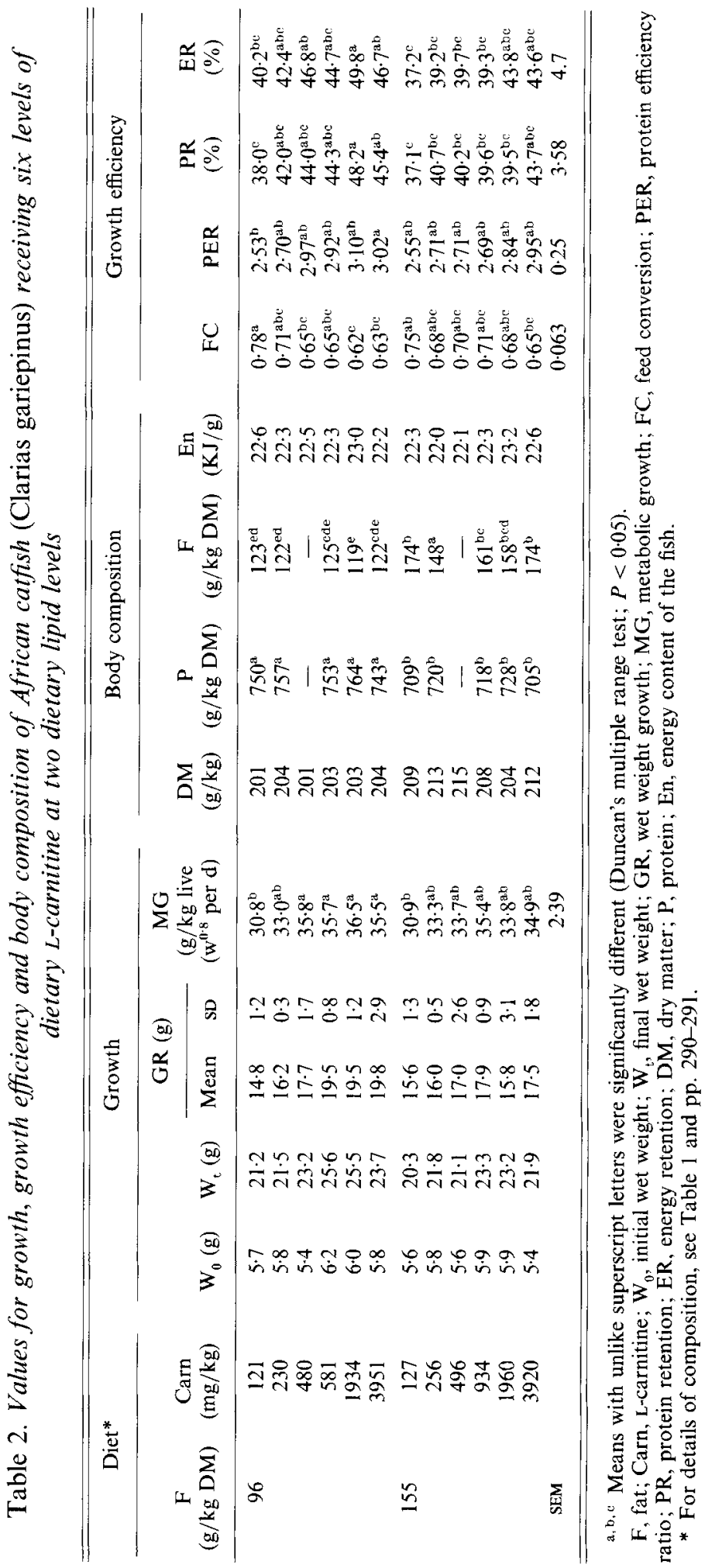




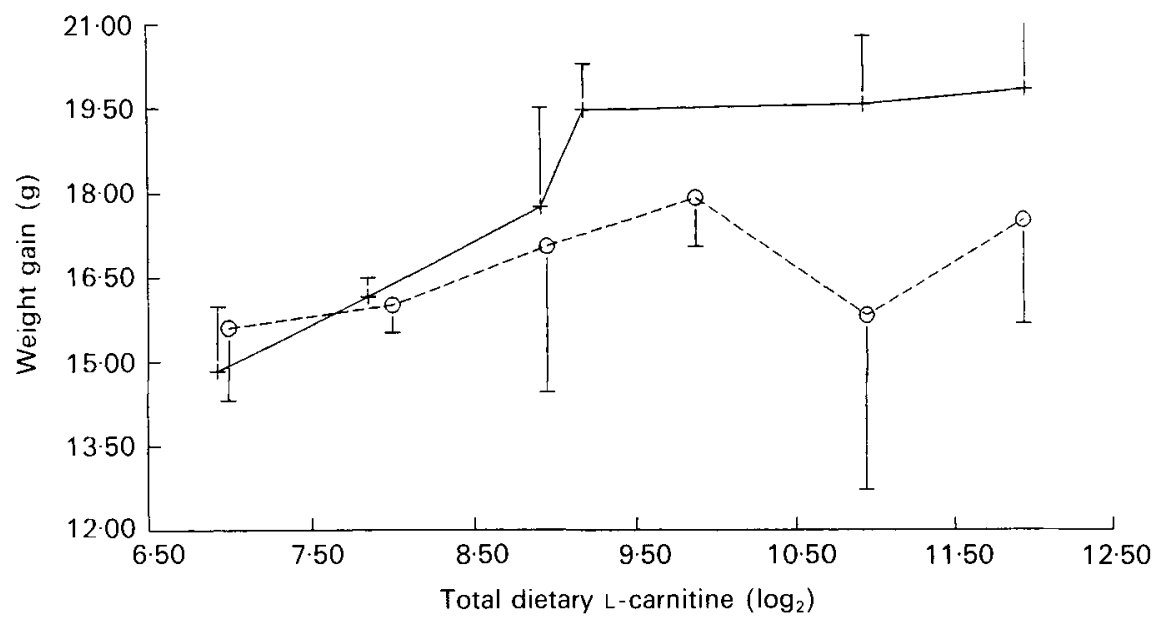

Fig. 1. The growth ( $\mathrm{g}$ ) of African catfish (Clarias gariepinus) fingerlings in relation to increasing levels of dietary $\mathrm{L}$-carnitine and at two dietary fat levels, $96(+-+)$ and $155\left(\mathrm{O}_{--} \mathrm{O}\right) \mathrm{g} / \mathrm{kg}$. Points are means and standard deviations represented by vertical bars. For details of diets and procedures, see Table 1 and pp. $290-292$.

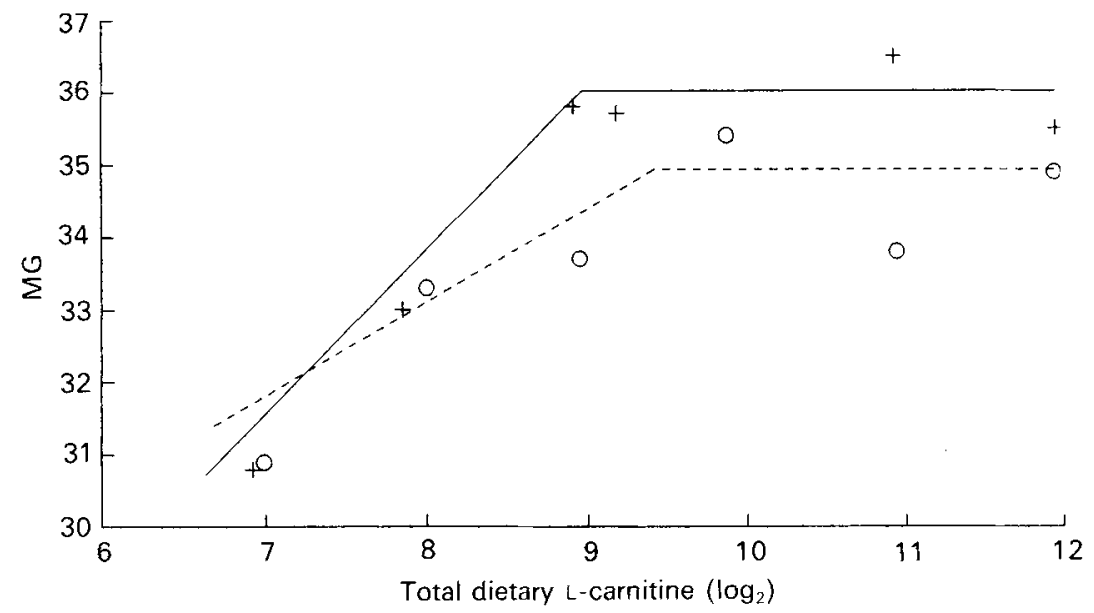

Fig. 2. Metabolic growth ( $\mathrm{MG} ; \mathrm{g} / \mathrm{kg}$ live weight ${ }^{08}$ per d) in African catfish (Clarias gariepinus) fingerlings in relation to increasing levels of dietary $\mathrm{L}$-carnitine and two dietary fat levels, $96(+-+)$ and $155(\mathrm{O}--\mathrm{O}) \mathrm{g} / \mathrm{kg}$. Curve fitting was done according to the Fortran procedure ZXLMIN. The initial slope is given by $\mathrm{MG}=$ $13.34+2.5 X(96 \mathrm{~g} \mathrm{fat} / \mathrm{kg})$ and $M G=21 \cdot 15+1.44 X(155 \mathrm{~g} \mathrm{fat} / \mathrm{kg}) ;$ for details, see p. 292 . For details of diets and procedures, see Table 1 and pp. 290-292.

significant L-carnitine effect $(P=0.0518)$, or a significant fat effect $(P=0 \cdot 1622)$, or a significant interaction effect $(P=0 \cdot 863)$.

PR levels increased from 38 to $48 \cdot 15 \%$ at the low dietary fat level and from $37 \cdot 1$ to $43.65 \%$ at the high dietary fat level. The effects both of $\mathrm{L}$-carnitine and fat were significant $(P=0.0432$ and $P=0.0081$ respectively). The interaction term was not significant $(P=0.5073)$.

ER increased from $40 \cdot 24$ to $49.8 \%$ at the $96 \mathrm{~g}$ fat $/ \mathrm{kg}$ level and from $37 \cdot 3$ to $43.75 \%$ at the $155 \mathrm{~g}$ fat $/ \mathrm{kg}$ level. As for PR, a significant effect of dietary L-carnitine level and fat was found for the ER $(P=0.0386$ and $P=0.0032$ respectively). No significant interaction effect was found $(P=0.327)$. 


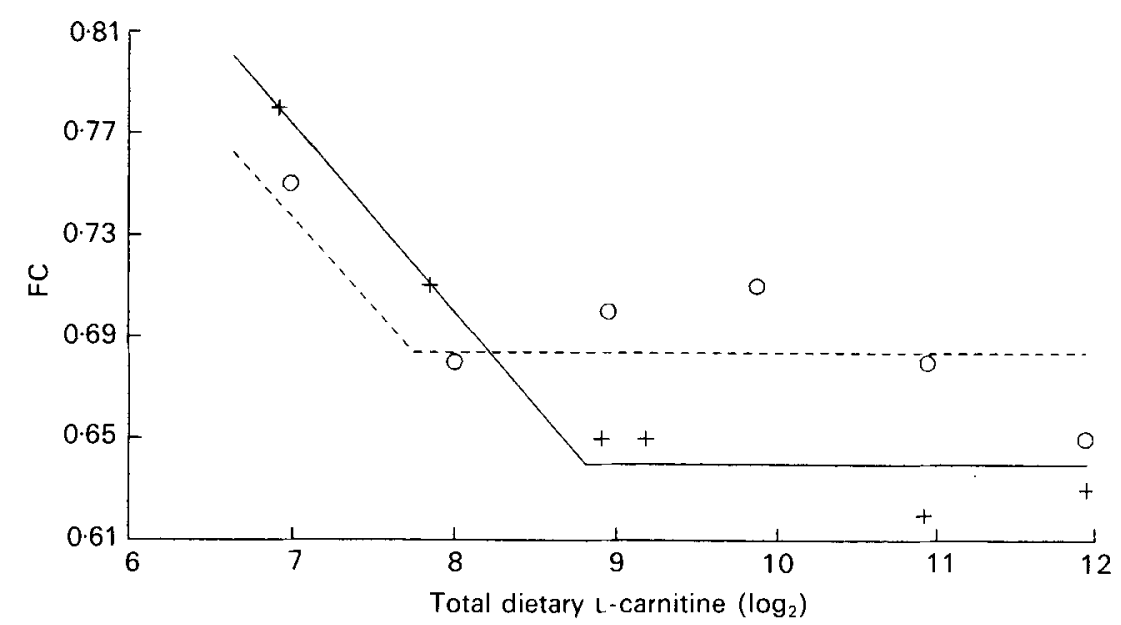

Fig. 3. Feed conversion (FC) $(\mathrm{g} / \mathrm{g})$ in African catish (Clarias gariepinus) fingerlings in relation to increasing levels of dietary L-carnitine and two dietary fat levels, $96(+-+)$ and $155(\mathrm{O}--\mathrm{O}) \mathrm{g} / \mathrm{kg}$. Curve fitting was done according to the Fortran procedure ZXLMIN. The initial slope is given by $\mathrm{FC}=1.3-0.075 X(96 \mathrm{~g}$ fat $/ \mathrm{kg})$ and by $\mathrm{FC}=1.27-0.074 X(155 \mathrm{~g}$ fat $/ \mathrm{kg})$; for details, see $\mathrm{p} .290$. For details of diets and procedures, see Table 1 and pp. $290-292$.

\section{DISCUSSION}

As the packed cell volume values were all above $30 \%$ and the colour of the plasma ranged from yellow to pale yellow, it was concluded that the fish tested were healthy and in good condition (J. H. Boon, personal communication).

The present study showed a positive effect of increased concentrations of dietary Lcarnitine on the growth rate and FC of African catfish fingerlings. According to the linearplateau model, a maximal growth rate of $35.9 \mathrm{~g} / \mathrm{kg} \mathrm{w}^{0.8}$ per d was obtained at a dietary Lcarnitine level of $500 \mathrm{mg} / \mathrm{kg}$ and a dietary fat level of $96 \mathrm{~g} / \mathrm{kg}$. For the diets with $155 \mathrm{~g}$ $\mathrm{fat} / \mathrm{kg}$ the growth rate was maximum at a level of $34.7 \mathrm{~g} / \mathrm{kg} \mathrm{w}^{0.8}$ per $\mathrm{d}$ at a L-carnitine level of $680 \mathrm{mg} / \mathrm{kg}$.

Translated into practical fish farming terminology, these findings signify that for African catfish the addition of 375 and $555 \mathrm{mg}$ L-carnitine $/ \mathrm{kg}$ respectively to feeds with respectively 96 and $155 \mathrm{~g}$ fat $/ \mathrm{kg}$, would result in a growth improvement of 16.5 and $12.3 \%$ respectively compared with common diets without L-carnitine supplementation. Tilapia (Oreochromis niloticus) receiving a similar dose of supplementary L-carnitine $(300 \mathrm{mg} / \mathrm{kg})$ realized a growth improvement of $8 \%$ (K. D. Gunther, unpublished results). When feeding a supplement of $1000 \mathrm{mg} / \mathrm{kg}$ to $12.2 \mathrm{~g}$ Channel catfish (Ictalurus punctatus), Burtle (1993) found a growth improvement of $15.6 \%$.

Recalculating the values of Burtle (1993), the optimal L-carnitine supplementation of $1000 \mathrm{mg} / \mathrm{kg}$ for channel catfish corresponds to a daily L-carnitine intake of $12.3 \mathrm{mg} / \mathrm{kg} \mathrm{w}$ per $\mathrm{d}$. In the present study with African catfish the optimum L-carnitine supplement of $500 \mathrm{mg} / \mathrm{kg}$ corresponds with a daily L-carnitine intake of $12.5 \mathrm{mg} / \mathrm{kg} \mathrm{w}^{0.8}$ per d. Apparently, in both studies the growth improvement was maximum at very similar L-carnitine intake levels. It is also very remarkable that these intake levels resulted in very similar relative growth improvements (15.6\% for channel catfish by Burtle (1993) and 16.5\% for African catfish in the present study). This comparison suggests that it is not the dietary L-carnitine level but the daily L-carnitine intake which determines the growth response. The difference between the two studies in the optimum dietary L-carnitine level can be explained by the difference in feeding level. Burtle (1993) fed his fish at a level of $30 \mathrm{~g} / \mathrm{kg}$ body weight per 
$\mathrm{d}$, which is equivalent to about $12 \cdot 3 \mathrm{~g} / \mathrm{kg} \mathrm{w}^{\mathbf{0} \cdot 8}$ per $\mathrm{d}$. This is about $50 \%$ of the feeding level applied in the present study.

As mentioned previously, dietary L-carnitine has a clear positive effect on growth efficiency in the African catfish. However, L-carnitine is an expensive product and the use of intermediate concentrations might be more cost effective than the L-carnitine levels required for maximum growth rate. Therefore, L-carnitine supplementation efficiency was calculated which indicates the increase in metabolic growth per unit supplementary Lcarnitine. In Table 3 the efficiency values for the levels of supplementation up to the maximum growth rate of the $96 \mathrm{~g}$ fat $/ \mathrm{kg}$ diet are assembled. The L-carnitine supplementation efficiency decreases asymptotically with increasing level of supplementation, suggesting an arbitrary inflexion point around $200 \mathrm{mg} / \mathrm{kg}$ which, therefore, can be regarded as the most cost effective level of $\mathrm{L}$-carnitine supplementation. According to the linear-plateau model, at this level of supplementation a growth improvement of about $10 \%$ (Table 3 ) should be feasible. This might make L-carnitine supplementation of African catfish diets economically viable.

Apparently, natural levels of L-carnitine in commercial diets are not sufficient to alleviate possible limitations in L-carnitine supply through biosynthesis. Since the biosynthesis of Lcarnitine may be impaired, particularly in the early stages of life (Bremer, 1983; Borum, 1987; Feller \& Rudman, 1988), it is assumed that the present findings may be related to such an impairment of the L-carnitine biosynthesis in these young catfish.

Theoretically, the positive effect of dietary L-carnitine may be attributed to an increased feed intake. However, the results of the present study do not support this hypothesis. All fish received the same amount of feed which was eaten voraciously according to visual observation. Hence, differences in growth rate must be attributed to differences in diet utilization. This suggestion is further corroborated by the positive effect of increasing dietary L-carnitine on FC as found in the present study. All diets with L-carnitine levels above 121 and $127 \mathrm{mg} / \mathrm{kg}$ respectively for low- and high-fat diets were more efficiently converted into weight gain than the control diets. In trout, rat, pigs, broiler chickens and humans, supplementary L-carnitine facilitates the transport of long-chain fatty acids into the mitochondria, resulting in extra energy from $\beta$-oxidation (Bilinski \& Jonas, 1970 ; Rebouche, 1983; Borum, 1987; Newton \& Haydon, 1987). The same process is assumed to be the basis for the growth improvement in the present study.

Since L-carnitine increases the energy obtained from fat, it was expected that the maximum growth rate would be higher and could be reached at higher L-carnitine levels in fat-rich diets. However, the present study did not demonstrate a significant dietary fat effect on MG, FC or PER. The plateau levels attained higher values at the lower dietary fat level. Two factors may be associated with the absence of this effect. At the low levels of fat a maximum oxidation of fat may have been reached. On the other hand, the composition of the dietary lipid may have influenced the results since L-carnitine is mainly of importance for the oxidation of long-chain fatty acids. No information was available about the fatty acid composition of the diets. Further, the carbohydrate levels vary with the dietary fat levels (Table 1). The $155 \mathrm{~g}$ fat $/ \mathrm{kg}$ diet contained $185 \mathrm{~g}$ carbohydrate $/ \mathrm{kg}$, while the $96 \mathrm{~g}$ fat $/ \mathrm{kg}$ diet contained $265 \mathrm{~g}$ carbohydrate $/ \mathrm{kg}$. Nishida et al. (1989) also found L-carnitine to be an important factor in the regulation of the glycogen synthesis. Therefore, in the present study dietary L-carnitine may have interacted, also, with the conversion of dietary carbohydrates into glycogen.

In conclusion, supplementary L-carnitine in the diets of the African catfish resulted in an increased growth performance, probably because of stimulation of protein-sparing action. Intermediate levels of supplementation arbitrarily set at $200 \mathrm{mg} / \mathrm{kg}$, may be the most cost effective. To elucidate in more detail the effect of L-carnitine, assessments of enzyme 
Table 3. The relative increase in metabolic growth and the L-carnitine supplementation efficiency (CSE; increase in metabolic growth/unit supplemented L-carnitine) in the African catfish (Clarias gariepinus), receiving diets containing $96 \mathrm{~g}$ fat $/ \mathrm{kg}$ and increasing concentrations of dietary L-carnitine

(Only values up to the L-carnitine level at which maximal growth improvement was attained, are given.

(For details, see pp. 293-294)

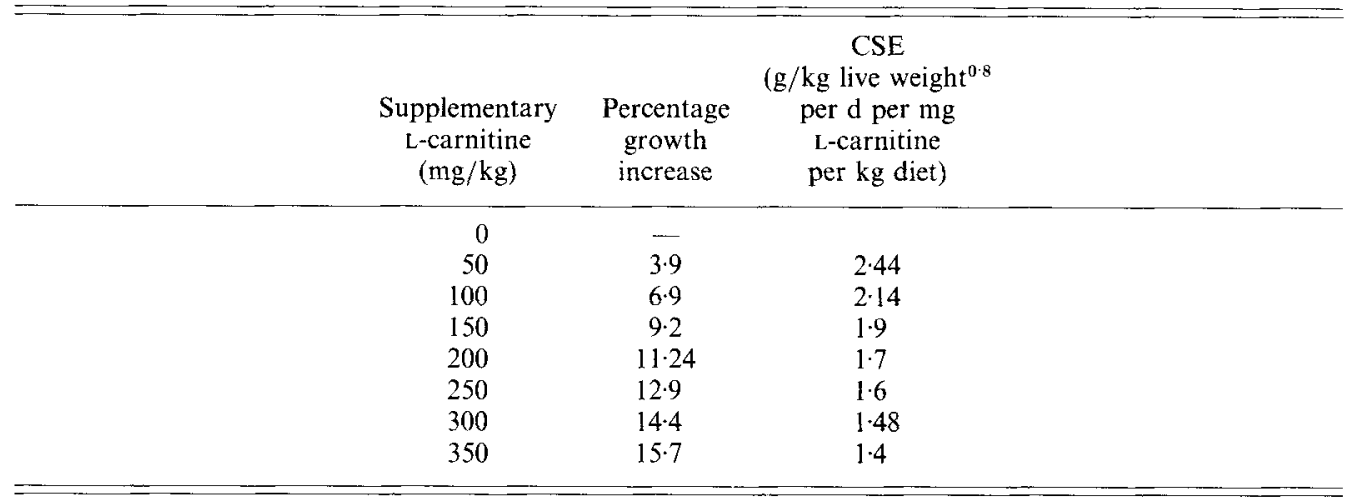

activities such as of carnitine acetyltransferase $(E C 2.3 .1 .7)$ and carnitine palmitoyltransferase (EC 2.3.1.21) and concomitant analyses of L-carnitine concentrations in different organ tissues would be most helpful. Further, a more detailed study of the fat composition, i.e. long-chain:medium-chain:short-chain fatty acids values, would be advantageous. Future studies should include isonitrogenous and isoenergetic diets to avoid possible interactions with varying carbohydrate and/or energy levels in the diets.

The present study was carried out under sponsorship from Lonza Ltd, Basel, Switzerland, under a bilateral contract research agreement between Lonza Ltd and the Wageningen Agricultural University. Drs W. Huizinga (LONZA Benelux bv, Rotterdam) is gratefully acknowledged for his continuous support and for supplying the L-carnitine. Dr J. W. Resink (Trouw International, Boxmeer) formulated the diets and Dr F. Brawand (Vitamin Institute, Basel, Switzerland) was responsible for the analysis of the dietary Lcarnitine levels. The research was carried out at the experimental rearing facilities of the Department of Fish Culture and Fisheries, Wageningen Agricultural University. $\mathrm{Mr}$ $\mathrm{S}$. Leenstra and $\mathrm{Mr} \mathrm{A}$. Hutten (Experimental hatchery De Haar-Vissen) are acknowledged for their continuous help and technical advice. Mr Luc Janss, Department of Animal Breeding, Wageningen Agricultural University is gratefully acknowledged for his help in developing the Fortran program to fit the linear plateau model. Special thanks are due to Professor Dr M. W. A. Verstegen, Department of Animal Nutrition, Wageningen Agricultural University, for his critical review of the manuscript.

\section{REFERENCES}

Bilinski, E. \& Jonas, R. E. E. (1970). Effects of coenzyme A and carnitine on the fatty acid oxidation by rainbow trout mitochondria. Journal of the Fisheries Research Board of Canada 27, 857-864.

Borum, P. T. (1987). Role of carnitine in lipid metabolism. In Lipids in Modern Nutrition, pp. 51-58 [M. Horisberger and U. Bracco, editors]. New York: M. Nestlé Nutrition, Vevey/Raven Press.

Bremer, J. (1983). Carnitine metabolism and functions. Annual Review of Physiology 63, 1420-1480.

Burtle, G. J. (1993). Effects of dietary L-carnitine supplements on growth and muscle lipid of fingerling Channel catfish. Journal of the World Aquaculture Society $\mathbf{2 4}$ (In the press). 
Feller, A. G. \& Rudman, D. (1988). Role of carnitine in human nutrition. Journal of Nutrition 118, $541-547$.

IMSL (1984). User's Manual. International Mathematical and Statistical Library, FORTRAN Subroutines for Mathematics and Statistics, vol. 3, ed. 9.2. Houston, Texas: IMSL Inc.

Machiels, M. A. M. \& Henken, A. M. (1986). A dynamic simulation model for growth of the African catfish, Clarias gariepinus (Burchell, 1822). II. Effect of feed composition on growth and energy metabolism. Aquaculture 60, 33-53.

Newton, G. L. \& Haydon, K. D. (1987). Carnitine in nursery pig diets. University of Georgia Swine Report, Special Publication no. 44, pp. 45-49. Athens, GA, USA: College of Agriculture.

Nishida, N., Sugimoto, T. \& Kobayashi, Y. (1989). Effect of L-carnitine on glycogen synthesis and ATPproduction of cultured hepatocytes of the newborn rat. Journal of Nutrition 119, 1705-1708.

Post, G. (1987). Textbook of Fish Health. Neptune City, USA: THF Publication Inc.

Rebouche, C. J. (1983). Effect of dietary carnitine isomers and gamma-butyrobetaine on L-carnitine biosynthesis and metabolism in the rat. Journal of Nutrition 113, 1906-1913.

Santulli, A. \& D'Amelio, V. (1986a). The effects of carnitine on the growth of sea bass (Dicentrachus labrax) fry. Journal of Fish Biology 28, 81-86.

Santulli, A. \& D'Amelio, V. (1986b). Supplemental dietary carnitine effects on growth and lipid metabolism of hatchery-reared sea bass (Dicentrachus labrax L.). Aquaculture 59, 177-186.

Santulli, A., Modica, A., Curatolo, A. \& D'Amelio, V. (1988). Carnitine administration to sea bass (Dicentrachus labrax L.) during feeding on a fat diet: modification of plasma lipid levels and lipoprotein pattern. Aquaculture 68, 345-351.

SAS Institute Inc. (1985). Statistics. SAS User's Guide. Cory, NC: SAS Institute Inc.

Sokal, R. R. \& Rohlf, F. (1981). Biometry: the Principles and Practice of Statistics in Biological Research, 2 nd ed. San Francisco: Freeman.

Stryer, L. (1988). Biochemistry, 3rd ed. pp. 434-568. New York: Freeman 